\title{
Breast cancer in adolescent and young adult Ivory coast women: epidemiological and clinical features and molecular subdivision
}

\author{
Edele Kacou Aka ${ }^{1 *}$, Apollinaire Horo ${ }^{1}$, Abdoul Koffi ${ }^{1}$, \\ Mohamed Fanny ${ }^{1}$, Coulibaly Didi-Kouko ${ }^{2}$, Guy Nda $^{3}$, \\ Alain Abouna ${ }^{4}$, Mamourou Kone ${ }^{5}$
}

\footnotetext{
${ }^{1}$ Teaching Hospital of Yopougon-Abidjan/ Obstetrics and Gynecology Unit (Abidjan-Cote d'Ivoire)

${ }^{2}$ Teaching Hospital of Treichville-Abidjan/ Oncology Unit (Abidjan-Cote d'Ivoire)

${ }^{3}$ Ivoirian Cancer Registry, (Abidjan-Cote d'Ivoire)

${ }^{4}$ Teaching Hospital of Cocody-Abidjan/ Anatomy-Pathology Unit (Abidjan-Cote d'Ivoire)
}

Received: 10 November 2020

Revised: 03 February 2021

Accepted: 04 February 2021

\section{*Correspondence:}

Dr. Edele Kacou Aka,

E-mail: edelpap@gmail.com

Copyright: (c) the author(s), publisher and licensee Medip Academy. This is an open-access article distributed under the terms of the Creative Commons Attribution Non-Commercial License, which permits unrestricted non-commercial use, distribution, and reproduction in any medium, provided the original work is properly cited.

\section{ABSTRACT}

Background: To describe the anatomy and clinical features and then determine the histological and molecular profile of Ivorian women under 40 years.

Methods: This is a retrospective multi-centre study descriptive and analytic performed over a period of 20 months. It involved 76 women on 355 selected in the Ivoirian cancer registry. An additional immunohistochemical analysis to assess hormone receptors and HER overexpression in a single unit.

Results: Adolescents and young adults represented $20.3 \%$ of women with breast cancer. The average age of women was 35 years. $(\partial=3.4$ years, $95 \% \mathrm{CI}=[2.6415$ to 4.1785$]) .15 .8 \%$ of patients had a good socioeconomic level with a stable job, well paid and $28.9 \%$ had a university degree. The discovery circumstances were a breast nodule $(53 \%)$ followed by locoregional complications (21\%) and breast self-examination (20\%). The consultation delay was less than three months in $34.2 \%$ of cases. $78 \%$ of cancers were diagnosed in stage II and III. The most common histological subtypes were respectively RP (+) / Her (-) (41\%) followed by triple negative (30\%).

Conclusions: This study showed that $20,3 \%$ of women under 40 years. The most tumors were classified as stage II and III of tumors at diagnosis. the most common histologic subtypes are the Luminal A (41\%) and triple-negative (30\%). This disease is more aggressive with a poor prognosis in this age group.

Keywords: Breast cancer, Adolescents and young adults, Molecular profile, Côte d'Ivoire

\section{INTRODUCTION}

Breast cancer is the first female cancer worldwide. According to the report GLOBOCAN 2012, it represents $1,671,149$ over annual new cases whose 133,890 cases in Africa. ${ }^{1}$ This cancer accounts for about $23 \%$ of all malignant tumors of women, and its incidence is increasing. ${ }^{2}$ In Ivory Coast, Breast cancer has become the first female cancer. According to data by the Ivoirian cancer registry, the incidence and mortality from breast cancer are rising steadily from 21.4 to 33.7 for 100,000 women and from 11 to $18.5 \%$ from 1997 to $2012 .{ }^{3}$ It is most frequently diagnosed cancer among in adolescent and young adult (AJA) women 15 to 39 years of age. It represents approximately $14 \%$ of all AYA cancer diagnoses and $7 \%$ of all breast cancer diagnoses. ${ }^{4,5}$ Several studies suggesting that breast cancer in this age group is more aggressive and associated with worse prognosis than their older counterparts. ${ }^{6}$ This specificity may be related to delayed diagnosis due to low socio-economic level of the 
populations concerned, a lack of information, awareness, mass screening, and insufficient technical platform. ${ }^{7}$ It is the largest age group in Africa and constitutes a big part of the working population of the continent.

The aggressiveness and the worse prognosis of breast cancer are not only due to age. It is a heterogeneous disease encompassing several distinct molecular profiles with different clinical behavior and different responses to treatment. Currently, patients with breast cancer are managed according to clinical and histological parameters, such as tumor size, lymph node involvement, in the presence or absence of hormone receptor (HR) the estrogen receptor (ER) and progesterone receptor (PR) and overexpression of human epidermal growth factor 2 (HER2) including age. Indeed, during the last decade, genomics and molecular profiling have led to a new molecular classification with at least four major subtypes associated with differences in survival and thereby conditioning the care and response to therapy. ${ }^{8-10} \mathrm{~A}$ better understanding of the natural history of this disease has led to improved therapeutic approaches and adapt them to the women and the subtype of cancer. The main objective of this study is to report the experience of Côte d'Ivoire in the personalized care of women under 40 living with breast cancer.

\section{METHODS}

This is a multicenter retrospective study descriptive and analytical referred, which took place from January 2013 to June 2015 an 18-month period. The services identified were those of Gynaecology Obstetrics of Treichville and Yopougon CHUs, radiology CHU Treichville, Cancerologie CHU Treichville, the cancer registry, pathology and anatomy laboratories CHUs Treichville and Cocody and laboratory central plateau. We obtained from the Ivoirian cancer registry (ICR) information about all female Ivoirian residents diagnosed with invasive breast cancer during the period January 2014, through June 2015. Individual informed consent was not obtained, as the analysis was based on cancer registry data. For each breast cancer case, we obtained information routinely abstracted from the medical record on age at diagnosis, AJCC stage at diagnosis (I, II, III, IV), grade (low, high,), ER, PR, and HER2 tumor-expression status, sequence number (first primary or non-first primary), and prior cancer (no, yes, or unknown). The ICR has collected information on breast cancer in Côte d'Ivoire since 2007 after a break in 1997. Before the October 2013, all of the cases lacked ER, EP, HER2, Ki67 data. Because all of the cases had no additional immunohistochemical analysis to assess hormone receptors and HER overexpression.

The histological diagnosis has-been performed in the pathology unit CHUs Treichville and Cocody on the micro biopsy, lumpectomy or mastectomy. Then, paraffin blocks or samples were sent to the central laboratory of pathological anatomy of the Plateau for the hormone receptor and Her2 search by immunohistochemistry PLC
Ventana Benchmark GX. Three antibodies were used: RO (SP1 clone), PR (1E2 clone), HER2 / neu (4B5 clone). The positivity threshold in our study retained was $10 \%$ for hormone receptors like in Europe unlike the 1\% threshold retained by ASCO. ${ }^{11}$ Overexpression HER2 Oncoprotein is regarded as positive for a score $2+$ and $3+$ as recommended by the assessment panel of immunohistochemical prognostic factoring in breast cancers (GFCI). ${ }^{12}$ The positive value of the index prognosis Ki 67 percent was a limit of $15 \%$. These exams allowed to determine five molecular subtypes which are: Luminal A, Luminal B (HER2- and HER2 +), no Luminal HER2+ and Triple-negative or carcinoma basal-like. Of the 2208 female invasive breast cancer cases older diagnosed between September 2007 and June 2015, we excluded cases lacked ER, PR, HER2, Ki67. The resulting study population $(\mathrm{N}=355)$ included 76 women aged 15 to 39 years. Data analysis was done using the software Epi Info 7, excel, word

\section{RESULTS}

Adolescents and young adults represented $20.3 \%$ of women with breast cancer.

Table 1: Distribution of 76 Ivoirian women according to age.

\begin{tabular}{|llll|}
\hline $\begin{array}{l}\text { Age } \\
(\text { years })\end{array}$ & $\begin{array}{l}\text { Effective } \\
(\mathbf{n})\end{array}$ & $\begin{array}{l}\text { Percentage } \\
(\%)\end{array}$ & $\begin{array}{l}\text { Cumulative } \\
\text { frequency } \\
(\%)\end{array}$ \\
\hline $\mathbf{1 5 - 1 9}$ & 0 & 0 & 0 \\
\hline $\mathbf{2 0 - 2 4}$ & 2 & 2.6 & 2.6 \\
\hline $\mathbf{2 5 - 2 9}$ & 3 & 3.9 & 6.5 \\
\hline $\mathbf{3 0 - 3 4}$ & 23 & 30.3 & 36.8 \\
\hline $\mathbf{3 5 - 3 9}$ & 48 & 63.2 & 100.0 \\
\hline Total & 76 & 100 & \\
\hline
\end{tabular}

Table 2: Distribution of 76 Ivoirian women according to profession and attainment level.

\begin{tabular}{|llll|}
\hline & & $\begin{array}{l}\text { Effective } \\
\text { (n) }\end{array}$ & $\%$ \\
\hline Attainment & Primary & 26 & 34.2 \\
\hline level & Secondary & 28 & 36.9 \\
\hline & University & 22 & 28.9 \\
\hline Profession & No income & 26 & 34.2 \\
\hline & Low income & 38 & 50 \\
\hline Regular & 12 & 15.8 \\
\hline Total & income & 76 & 100 \\
\hline
\end{tabular}

The average age of women was 35 years. $(\partial=3.4$ years, $95 \% \mathrm{CI}=[2.6415$ to 4.1785$]) .36 .8 \%$ of women had under 35 (Table 1). $15.8 \%$ of patients had a good socioeconomic level with a regular income and $28.9 \%$ had a university degree (Table 2). The discovery circumstances were a breast nodule (53\%) followed by locoregional 
complications (21\%) and breast self-examination (20\%). The consultation delay was less than three months in $34.2 \%$ of cases. $78 \%$ of cancers were diagnosed in stage II and III (Table 3). Radiological images were suggestive of malignancy (BI-RADS 5 according to ACR) in 54\% of cases and $39 \%$ of radiological images were suspects. The most common histological type was invasive carcinoma non-specific $(87 \%)$.

Table 3: Distribution of 76 Ivoirian women according to discoveries circumstances, consultation delay and stage of cancer.

\begin{tabular}{|llll|}
\hline \multirow{5}{*}{$\begin{array}{l}\text { Discoveries } \\
\text { circumstances }\end{array}$} & $\begin{array}{l}\text { Effective } \\
\text { (n) }\end{array}$ & $\%$ \\
\cline { 2 - 4 } & $\begin{array}{l}\text { Nodule } \\
\text { Loco-regional } \\
\text { complications }\end{array}$ & 40 & 53 \\
\cline { 2 - 4 } & $\begin{array}{l}\text { Breast self- } \\
\text { examination }\end{array}$ & 16 & 21 \\
\cline { 2 - 4 } Consultation & Others & 5 & 20 \\
\hline \multirow{5}{*}{ delay } & $\leq 3$ months & 26 & 34.2 \\
\hline \multirow{2}{*}{ Stage } & $>3$ months & 50 & 65.8 \\
& I & 15 & 20 \\
\hline & II & 31 & 41 \\
\cline { 2 - 4 } & III & 28 & 37 \\
\hline & IV & 2 & 3 \\
\hline
\end{tabular}

Table 4: Distribution of 76 Ivoirian women according to molecular profile.

\begin{tabular}{|lll|}
\hline Molecumar profile & $\begin{array}{l}\text { Effective } \\
\text { (n) }\end{array}$ & $\%$ \\
\hline $\begin{array}{l}\text { Luminal A (RE+ et/ou RP+ } \\
\text { Her2, grade IouII) }\end{array}$ & 31 & 41.0 \\
\hline $\begin{array}{l}\text { Luminal B Her 2 - (RE+ et/ou } \\
\text { RP+ Her2-, grade III) }\end{array}$ & 8 & 10.5 \\
\hline Luminal B Her 2 + & 6 & 8.0 \\
\hline Her 2 + non luminal & 8 & 10.5 \\
\hline Basal-like & 23 & 30.0 \\
\hline Total & 76 & 100.0 \\
\hline
\end{tabular}

The ELSTON-ELLIS score was 2 and 3 in $96 \%$ of cases. The most common histological subtypes were respectively RP (+) / Her (-) (41\%) followed by triple negative (30\%) (Table 4).

\section{DISCUSSION}

\section{Clinical and epidemiological features}

Breast cancer in patients under 40 years is rare; however, it has attracted considerable interest because of the associated adverse outcome reported in several studies. ${ }^{6,13,14}$ The average age of breast cancer diagnosis in women is usually is around 50-60 years. ${ }^{15}$ In the US, about $7 \%$ of cases of breast cancer are diagnosed in women under 40 years. ${ }^{4,5}$ In our study, this age group represents $20.3 \%$ of all women with breast cancer and the average age was 35 years. This high proportion is due to the fact that the Ivorian population like that of other African countries is predominantly young, unlike western countries.

Nevertheless, many reports indicate that the poor results associated with this age group are complicated by more other factors. ${ }^{14,16,17}$. Several studies in the United States have shown particular racial and ethnic in breast cancer occurred. Thus, the American black population under 40 were more likely to develop the disease compared to white female $(6.6 \%$ versus $3.6 \%)$. ${ }^{18}$ Some studies also show an influence of low socioeconomic level on breast cancer incidence and prognosis. ${ }^{19}$ In fact, only $15,8 \%$ of our sample had a good socioeconomic level with a stable job, well paid and less than $28,9 \%$ was a university degree.

Several epidemiological studies have examined the risk factors for the subtypes of breast cancer using large enough specific data sets to provide sufficient statistical power to detect some differences between the subtypes of breast cancer. In a pooled meta-analysis of 34 observational studies of the Breast cancer association consortium (BCAC), reproductive risk factors (age at menarche, parity, and age at birth of first child) and Body mass index (BMI) have been associated with breast tumors ER or PR $+{ }^{20}$ For cons, the pooled analysis of 12 studies BCAC who had data on tumor HER2 status has not found an association between risk of triple-negative breast cancer and all other risk factors which are typically considered when the breast cancer study as a single entity, with the exception of family history. It was positively associated with the subtype of breast cancer triple negative. ${ }^{20}$ The higher incidence of breast cancer triple negative among black women than among white women at all ages suggests that black women are more sensitive to the triple negative breast cancer than white women, Hispanic or Asian. ${ }^{21,22}$ The no genetics features among which environmental may explain the higher incidence of triple negative breast cancer in black women than in white women. ${ }^{23}$ Future studies should look at an association between the risk factors and subtypes of breast cancer while considering the age and race and ethnicity.

Given the lack of routine mammography screening program for women aged under 40, It Seems obvious to see that this younger age group of women are likely to arise in consultation with a palpable mass with sometimes lymph node involvement. ${ }^{14,24,25}$ The discoveries of Circumstances in our study were palpable masses (53\%), loco regional complications like permeation nodules and lymphadenopathy $(21 \%)$ and breast self during palpation. (20\%). Although young women perform screening mammography, imaging is less sensitive than in postmenopausal women breast because of the breast tissue of young women can mask the radiological features of breast cancer at an early stage. ${ }^{26}$ Radiological images were suggestive of malignancy (BI-RADS 5 according to ACR) in $54 \%$ of cases and $39 \%$ of radiological images were suspect in our population. There is also a wide variability 
of radiological images according to the histological subtypes. $^{27}$

Specifically, in resource-poor countries like Côte d'Ivoire, for cultural, economic and social reasons, women often delay going to the doctor. In our study, $65 \%$ of women consulted three months after the occurrence of signs. Tumor size was higher than $2 \mathrm{~cm}$ in $78 \%$ of cases. The tumors were classified as stage II (41\%) and III (37\%) at diagnosis. These results agree with those of Bharat young women $(45.1 \%)$ were diagnosed at advanced stages of disease (II and III) compared to older women (30.9\%). with stage II tumors. ${ }^{24}$ It was determined that tumor pathology at an advanced stage, nodal status, and the presence of distant metastases at diagnosis contributes to a worse outcome in breast cancer in women younger than 40 years. ${ }^{25,28,29}$ Biological variability described above is likely to be the main factor responsible for the mortality disparities we observed, that young women have tumors that have adverse characteristics. This biological variability would have the most impact at an early stage. It is also possible that young women with the disease at an advanced stage (stage III and IV) are likely to undergo more aggressive treatment than older women with these stages due to their young age and lack of suspected comorbidities. However, the rate of mortality in increased among young women cancer was not only a result of the advanced stage of disease at diagnosis, as evidenced by the results significantly in the poorest women under 40 years with the earliest stages of the disease. In addition, breast cancer mortality in young women higher was also observed after adjusting for tumor stage..$^{30}$

\section{Histological features and molecular profile}

In this study, the standard histology analysis showed that the majority of young women were diagnosed with tumors in advanced stages. It was mostly (87\%) invasive carcinoma non-specific, followed by lobular carcinoma $(7.8 \%)$ and mixed type (2.6\%). ELSTON-ELLIS score was 2 and 3 in $96 \%$ of cases, a finding similar to that published in the literature. . $5,31,32^{2}$

The subtypes of breast cancer differ in various ways, including surface markers expressed, proliferative capacity, and the ability to respond to therapies. The basallike subtype was associated with poor clinical outcomes, can be attributed to its high proliferative capacity, lack of estrogen receptors, and the overexpression of HER-2, while luminal A subtype has been shown to have the best prognosis. ${ }^{24,33}$ Among Ivorian young women with breast cancer: $59.5 \%$ are type luminal (Luminal A $41 \%$ Luminal B HER2-10,5\% Luminal B HER2 + 8\%); HER2 + 10.5\% non-luminal and basal-like $30 \%$ or triple-negative. This reflects the aggressiveness and a worse prognosis as demonstrated by numerous studies worldwide. Our results are consistent with these. Our results are also consistent with previous studies based of California registry cancer which have found a higher overall incidence of breast cancer triple negative among black women and $\mathrm{HR}+$ /
HER2 + breast cancer in white women compared to women other racial and ethnic groups. ${ }^{23}$ Assi et al. also noted that breast cancer in younger women is associated with high-grade tumors, hormone receptor negativity and HER-2 neu overexpression. ${ }^{34}$ The prevalence of triplenegative among young women is reported to be low in a study in southern India, and these patient groups are likely to be less sensitive to the conventional treatment of hormonal and targeted antibodies. ${ }^{35}$

The strengths of this study are a good collaboration between the different units in which women have been assumed, a single center for the realization of the complementary immunohistochemistry of all samples from different centers and a good medical record keeping and archives. There is much weakness to our study, which is inherent in any retrospective cohort study including the inability to control for selection bias; the existence of missing data on some biomarkers as described in the individual pathology reports and lack of information at the individual level details of the breast cancer risk factors. The study period does not allow us also to appreciate the survival rate over a long period.

\section{CONCLUSION}

This study showed that $20.3 \%$ of women under 40 years. The most tumors were classified as stage II and III of tumors at diagnosis. the most common histologic subtypes are the Luminal A (41\%) and triple-negative (30\%). This disease is more aggressive with a poor prognosis in this age group. Molecular profiling and would adjust the treatment for longer survival.

\section{ACKNOWLEDGMENTS}

Authors would like to thank Ivoirian Registry of Cancer. Society of Gynecology and Obstetrics of Côte d'Ivoire (SOGOCI).

\section{Funding: No funding sources}

Conflict of interest: None declared

Ethical approval: The study was approved by the Institutional Ethics Committee

\section{REFERENCES}

1. Ferlay J, Soerjomataram I, Ervik M, Dikshit R, Eser S, Mathers C et al. GLOBOCAN 2012 V1.0, Cancer Incidence and Mortality Worldwide: IARC Cancer Base No.11 Lyon, France: International Agency for Research on Cancer. 2013.

2. Parkin DM, Bray F, Ferlay J, P Pisani. CA Cancer J Clin. 2005;55(2):74-108

3. Echimane AK, Ahnoux AA, Adoubi I, Hien S. Cancer incidence in Abidjan, Ivory Coast: first results from the cancer registry 1995-1997. Cancer in Word. 2000;86,3:653-63.

4. Bleyer A, R Barr, Hayes-Lattin B, Thomas D, C Ellis, Anderson B. The distinctive biology of cancer in 
adolescents and young adults. Nat Rev Cancer. 2008;8(4):288-98.

5. Gabriel CA, Domchek SM. Breast cancer in young women. Breast Cancer Res. 2010;12(5):212.

6. Gnerlich JL, Deshpande AD, Jeffe DB, Doux A, Blanc $\mathrm{N}$, le juge Margenthaler. Elevated breast cancer mortality in women younger than age 40 years compared with older women is attributed to poorer survival in earlystage disease. J Am Coll Surg. 2009;208(3):341-7.

7. Madani Ly, Martine A., Fabrice A. Le cancer du sein chez la femme de l'Afrique subsaharienne : état actuel des connaissances. Bull cancer. 2011;98(7):797-806.

8. Perou CM, Sørlie T, Eisen MB. Molecular portraits of human breast tumours. Nature $2000 ; 406: 747-52$.

9. Sørlie T, Perou CM, Tibshirani R. Gene expression patterns of breast carcinomas distinguish tumor subclasses with clinical implications. Proc Natl Acad Sci USA. $2001 ; 98: 10869-874$.

10. Carey LA, Perou CM, Livasy CA. Race, breast cancer subtypes, and survival in the Carolina Breast Cancer Study. JAMA. 2006 ;295:2492-502.

11. Hammond. ASCO/CAP Guideline Recommendations for Immunohistochemical Testing of Estrogen and Progesterone Receptors in Breast cancer. J Clin Oncol. 2010

12. Penault-Llorca F. Groupe d'Evaluation des Facteurs Pronostiques par Immunohistochimie dans les Cancers du Sein (GEFPICS). Ann Pathol. 2010;30:357-73.

13. Fredholm H, Eaker S, Frisell J, Holmberg L, Fredriksson I, Lindman H. Breast Cancer in Young Women: Poor Survival Despite Intensive Treatment. PLoS One. 2009;4(11):A38-46.

14. Bharat A, Aft RL, Gao F, Margenthaler JA. Patient and Tumor Characteristics Associated With Increased Mortality in Young Women ( $<=40$ Years) With Breast Cancer. Journal of Surgical Oncology. 2009;100(3):24851.

15. El Saghir NS. Effects of young age at presentation on survival in breast cancer. BMC Cancer. 2006;6:194.

16. Sidoni A, Cavaliere A, Bellezza G, Scheibel M, Bucciarelli E. Breast cancer in young women: clinicopthological features and biological specificity. 2003;12(4):247-50.

17. McAree B. Breast cancer in women under 40 years of age: a series of 57 cases from Northern Ireland. Breast. 2010;19(2):97-104.

18. Kurian AW, Fish K, Shema SJ, Clarke CJ. Lifetime risks of specific breast cancer subtypes among women in four racial/ethnic groups Breast Cancer Res. 2010;12(6).

19. Vona-Davis L, Rose DP. The influence of socioeconomic disparities on breast cancer tumor biology and prognosis: a review. J Womens Health (Larchmt). 2009;18(6):883-93.

20. Yang XR, Chang-Claude J, Goode EL. Associations of breast cancer risk factors with tumor subtypes: a pooled analysis from the Breast Cancer Association Consortium studies J Natl Cancer Inst. 2011;103(3):250-63.
21. Chagpar AB, Polk HC, Jr, McMasters KM. Racial trends in mammography rates: a population-based study Surgery. 2008;144(3):467-72.

22. Clarke CA, Keegan THM, Yang J. Age-Specific Incidence of Breast Cancer Subtypes: Understanding the Black-White Crossover J Natl Cancer Inst. 2012;104(14):1094-101.

23. Kurian AW. BRCA1 and BRCA2 mutations across race and ethnicity: distribution and clinical implications. Curr Opin Obstet Gynecol. 2010;22:72-78.

24. Thangjam S, Laishram RS, Debnath K. Breast carcinoma in young females below the age of 40 years: A histopathological perspective. South Asian J Cancer. 2014;3(2):97-100.

25. Boyd NF, Martin LJ, Sun L. Body size, mammographic density, and breast cancer risk. Cancer Epidemiol Biomarkers Prev. 2006;15:2086-092.

26. M. Boisserie-Lacroixa, B. Bullier a, G. HurteventLabrota. Corrélations imagerie-facteurs pronostiques classification moléculaire des cancers du sein. Journal de Radiologie Diagnostique et Interventionnelle. 2014;95:230-36.

27. Feldman AL, Welch JP. Long-term outcome in women less than 30 years of age with breast cancer. J Surg Oncol. 1998;68:193-8.

28. Livi L, Meattini I, Saieva C, Borghesi S, Scotti V, Petrucci A, et al. The impact of young age on breast cancer outcome. Eur J Surg Oncol. 2010;36:639-45.

29. Elkhuizen PH, van de Vijver MJ, Hermans J. Local recurrence after breast-conserving therapy for invasive breast cancer: high incidence in young patients and association with poor survival. Int $\mathbf{J}$ Radiat Oncol Biol Phys. 1998;40:859-67.

30. Kwong A, Cheung P, Chan S, Lau S. Breast cancer in Chinese women younger than age 40: Are they different from their older counterparts? World J Surg Onc. 2008;32:2554-61.

31. Cristofanilli M. Invasive lobular carcinoma classic type: Response to primary chemotherapy and survival outcomes. J Clin Oncol. 2005;23:41-8.

32. Sotiriou C, Neo SY, McShane LM. Breast cancer classification and prognosis based on gene expression profiles from a population-based study. Proc Natl Acad Sci USA. 2003;100:10393-0398.

33. Parise CA, Bauer KR, Caggiano V. Variation in breast cancer subtypes with age and race/ethnicity Crit Rev Oncol Hemat. 2010;76(1):44-52.

34. Assi HA. Epidemiology and prognosis of breast cancer in young women. J Thorac Dis. 2013;5:S2-8.

35. Rao C, Shetty J, Kishan Prasad HL. Morphological profile and receptor status in breast carcinoma: An institutional study. J Can Res Ther. 2013;9:44-9.

Cite this article as: Aka EK, Horo A, Koffi A, Fanny M, Didi-kouko C, Nda G et al. Breast cancer in adolescent and young adult ivory coast women: epidemiological and clinical features and molecular subdivision. Int J Reprod Contracept Obstet Gynecol 2021;10:848-52. 